\title{
Perceptions and Practices of Learning Styles in Library Instruction
}

\section{Connie Dalrymple}

\begin{abstract}
Learning style theory has gained a broad base of acceptance in the library field. Less clear is how well librarians have assimilated learning style theory and how consciously they are incorporating its tenets into their day-to-day teaching. This survey was conducted to ascertain how instruction librarians and other library professionals learn, assimilate, and utilize learning style theory. Results show that the majority of librarians are aware of learning style theory, but many are unsure of its validity or proper application in library settings. Recommendations include increased coverage of instructional theory in library schools and more rigorous scientific studies of learning style-sensitive practice in library instruction settings.
\end{abstract}

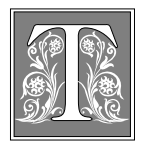

he concept of learning style has been defined in various ways. For the purposes of this article, a simplified definition is a given individual's learning preferences. The concept of learning styles, although it sounds simple, is actually quite complex. Thomas C. DeBello's 1990 article provided an overview of this complexity as it outlined the many dimensions of learning style as proposed by theorists in the field. ${ }^{1}$

Although many models of learning style theory exist, two are most often cited by librarians. One model, developed by Kenneth J. and Rita Stafford Dunn in the late 1960s, consists of emotional, environmental, physiological, psychological, and sociological dimensions with twenty-one subcategories. The Dunns' assessment instrument is the Learning Style Inventory, consisting of one hundred questions.

The perceptual modalities (visual, auditory, tactual, kinesthetic, and combination) often cited in the literature are part of the perceptual subcategory of the physiological category in the Dunn model. ${ }^{2}$

Howard Gardner's Theory of Multiple Intelligences, first published in 1983, outlined seven intelligences: linguistic, logical-mathematical, musical, bodily-kinesthetic, spatial, interpersonal, and intrapersonal. Additional intelligences have since been proposed. Though similar in concept, Gardner's framework was developed separately from the Dunns'. Cited frequently in the education literature, the Theory of Multiple Intelligences is mentioned infrequently in the literature of library science. ${ }^{3}$

Connie Dalrymple is an Assistant Professor and Life $\mathcal{E}$ Health Sciences Librarian at Wichita State University; e-mail: connie.dalrymple@wichita.edu. The author wishes to thank research assistant Fui-Nii Phang, who was of immense help and encouragement during the project. This research was supported by a grant from Wichita State University's University Research and Creative Projects Administration. 


\begin{tabular}{|lrc|}
\hline \multicolumn{3}{c|}{ TABLE 1 } \\
Organization Type \\
\hline \hline Variable & Frequency & Percent \\
\hline Academic library & 799 & 88.0 \\
Public library & 22 & 2.4 \\
School library & 21 & 2.3 \\
Medical library & 10 & 1.1 \\
Special library & 8 & 0.9 \\
State or federal library & 7 & 0.8 \\
School of library information science & 6 & 0.7 \\
Law library & 4 & 0.4 \\
Library system & 3 & 0.3 \\
Independent information brokerage & 2 & 0.2 \\
Other & 25 & 2.8 \\
\hline Total & 907 & 99.9 \\
1 missing case; 907 valid cases & & \\
\hline
\end{tabular}

tion on learning styles. ${ }^{5}$ He prefaced the article by reminding readers that, although we endeavor to treat all students as individuals, sometimes categorization can be a helpful tool. Sonia Bodi's papers outlined her application of Kolb's theory of experiential learning in the academic library setting. ${ }^{6}$ Elizabeth J. McNeer's 1991 article detailed the characteristics of college students at different levels of cognitive development and suggested strate-

The second model cited often in the library literature, the Experiential Learning Model, was envisioned by David Kolb. This model consists of two dimensions and is represented like the axes on a graph. At opposite poles of one dimension are Concrete Experience abilities and Abstract Conceptualization abilities. At the opposite poles of the second dimension are Reflective Observation abilities and Active/ Experimentation abilities. Individuals tend to fall into one of the four possible quadrants on the graph. According to Kolb, the four predominant types are the diverger, the assimilator, the converger, and the accomodator. Divergers need to know why they need to learn something, assimilators need to know what pieces of the puzzle they need to assimilate in order to learn a concept, convergers act pragmatically and want to find out how things work, and accomodators tend to be highly creative and to experiment in order to solve problems. ${ }^{4}$

The professional literature of librarianship is rich in references to the application of learning styles in library instruction. Much of it refers to the application of learning style theory to specific audiences. Daniel D. Barron's review article for school library media specialists detailed sources of background informa- gies for teaching to these levels. ${ }^{7}$ Eileen E. Allen recommended ways to increase student involvement in postsecondary library instruction through active learning techniques. ${ }^{8}$ The methods recommended in Allen's article, including incorporating pauses for group discussions, questioning, and short quizzes, could easily be adapted to work in other settings as well.

\section{Most librarians who had heard of learning style theory felt that it was valid or very valid, with 70.8 percent of respondents falling into these two categories.}

Some authors have taken the tack of showing how learning style theory can be applied to certain ethnic groups. Dorothy N. Bowen's research on Kenyan and Nigerian students is one example. ${ }^{9}$ Sally G. Wayman took a broader approach in her publications, giving examples of how individuals from various cultures might react in different situations such as group work or the classroom setting. ${ }^{10}$ Rita Dunn's articles cited studies proving the efficacy of applying learning style theory in the classroom and also discussed learning styles of different groups and the individual variance within them. ${ }^{11}$ 


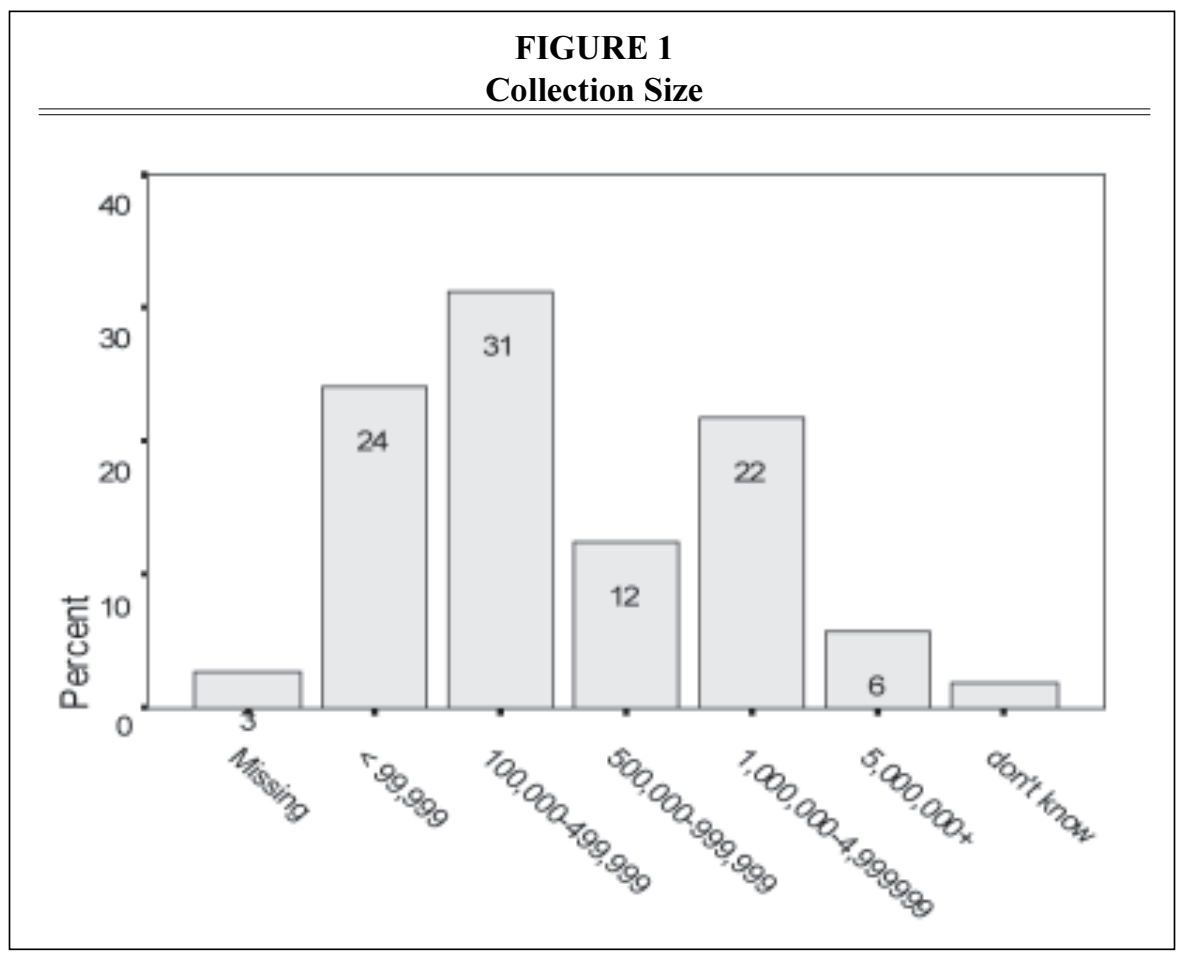

Another arena that librarians have considered is the application of learning style theory in different instructional settings. Keith Gresham focused on the electronic classroom in his 2000 article. ${ }^{12}$ Terri Holtze pointed out the importance of incorporating learning style theory into Web page design. ${ }^{13}$ She explained that because so many library users are bypassing the physical library and library instruction because of the Web accessibility of resources, Web portals must follow good instructional design principles. Randall Hensley's 1991 article described how learning style-sensitive instruction could be offered at the reference desk based on verbal and nonverbal cues in the reference interview. ${ }^{14}$ Learning style theory has even been adapted to very specific situations, as evidenced by Marie Carbo's reading styles research, which identified students' learning styles during the act of reading. ${ }^{15}$

The learning styles of librarians themselves also have been addressed in the literature. Jin M. Choi found that the most common learning styles among academic librarians were the assimilator and the converger, according to Kolb's Learning Style Inventory. ${ }^{16}$

There have been dozens of articles studying librarian and student learning styles and recommending instructional methods to accommodate them. Librarian learning style pioneers have not been shy about making their colleagues aware of this growing area of research. Clearly, learning style theory has gained a broad base of acceptance in the library field. But how well has this information been assimilated by librarians, and how often and how consciously are they incorporating the tenets of learning style theory into their day-to-day teaching? This survey was conducted to ascertain how instruction librarians and other librarians interested in user education learn, assimilate, and utilize learning style theory.

\section{Methodology}

The 33-question survey instrument described in this paper was pretested by a convenience sample of eleven persons: 


\begin{tabular}{|lcc|}
\hline \multicolumn{3}{c}{ TABLE 2} \\
\multicolumn{1}{|c|}{ Main Job Duties (Multiple Response) } \\
\hline \hline Variable & Frequency & $\begin{array}{c}\text { Percent } \\
\text { of Cases }\end{array}$ \\
\hline Reference & 634 & 70.2 \\
Administration & 482 & 53.4 \\
Instruction & 469 & 51.9 \\
Collection development & 415 & 46.0 \\
Research & 200 & 22.1 \\
Systems & 83 & 9.2 \\
Technical services & 78 & 8.6 \\
Circulation or reserve & 75 & 8.3 \\
Consulting & 70 & 7.8 \\
One-librarian library & 53 & 5.9 \\
Interlibrary loan & 47 & 5.2 \\
Archives & 21 & 2.3 \\
\hline Total responses & 2627 & 290.9 \\
5 missing cases; 903 valid cases & \\
\hline
\end{tabular}

Round Table, along with Instruction Section members, was leased from the ALA in April 2000. The surveys were distributed via U.S. mail in April 2000. Between April and August, respondents returned 908 surveys, for a return rate of 60.5 percent, providing results that fall within $+/-3$ percent at the 95 percent confidence level.

Data were analyzed using SPSS 10 for Windows. Spearman's rho was used to assess the correlation between nonparametric variables.

\section{Participant Demographics}

As shown in table 1, most respondents were from academic institutions, with lesser representation from other categories. A variety of sizes of institutions was represented, as illustrated in figure 1, nine academic librarians, a graduate student in business, and a marketing consultant. Final modifications to its content and presentation were based on their input.

A tab-delimited file containing name and address information for 1,500 members of the ALA's Library Instruction with a collection size of 100,000-499,999 being the largest category and with 40 percent of participants coming from large libraries with collections of more than 500,000 volumes. Table 2 shows the main job duties of the participants, with large numbers participating heavily in refer-

\section{FIGURE 2}

\section{Highest Degree Earned}

Missing

$.3 \%$

doctorate

$9.3 \%$

bachelor's

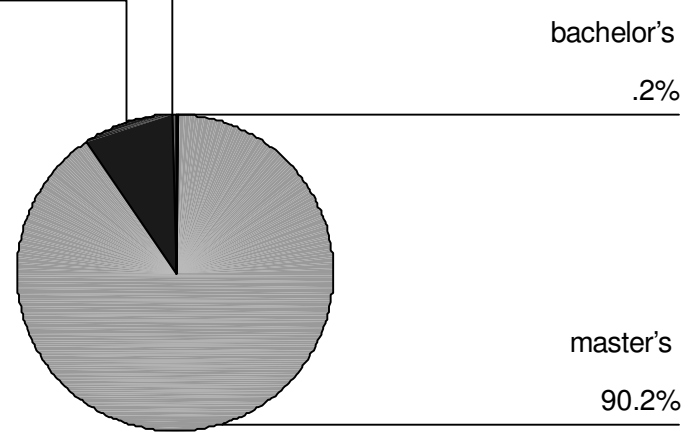




\begin{tabular}{|lcc|}
\hline \multicolumn{3}{|c|}{ TABLE 3 } \\
Library Science Education & Attainment \\
\hline \hline Variable & Frequency & Percent \\
\hline I have a master's degree in the field. & 873 & 96.3 \\
I have a Ph.D. in the field. & 22 & 2.4 \\
I have taken some course work & 4 & .4 \\
but earned no degree. & 4 & .4 \\
I have an associate's or bachelor's degree. & 4 & .4 \\
I have no formal library science education. & 4 & 99.9 \\
\hline Total responses & 907 & \\
6 missing cases; 902 valid cases & & \\
\hline
\end{tabular}

Results

Awareness of Learn-

ing Style Theory

Overall, the vast majority of participants (nearly $82 \%$ ) indicated that they have heard of learning style theory (figure 5). This high percentage is what one might expect, given the penetration of this concept into the professional literature of librarianship. There

ence, collection development, instruction, and administration. Most participants' highest-earned degree was a master's, as shown in figure 2 . Library science education is shown in table 3, with most respondents falling into the MLS category, as one might expect. As shown in figure 3 , most participants fell into the baby-boomer generation, born between 1946 and 1965 . Figure 4 shows that slightly more than 74 percent of respondents were female and slightly more than 25 percent were male. was a slight, but significant, positive correlation between awareness of learning style theory and:

- those with backgrounds involving significant course work in education;

- having been a K-12 teacher;

- the number of hours spent on duties relating to instructing library users;

- the type of current work organization. Participants working in academic libraries, school library media centers, and library schools had a slightly higher awareness of

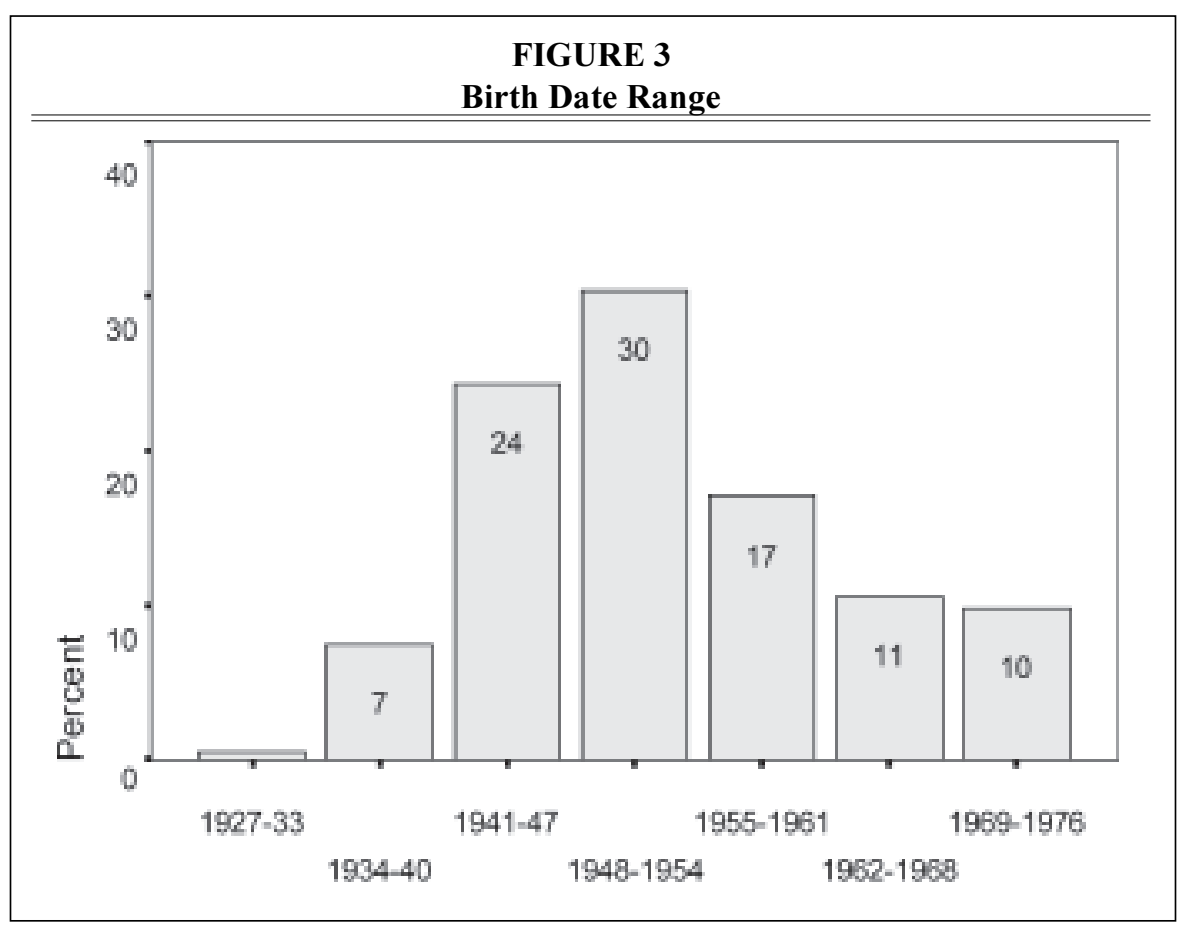




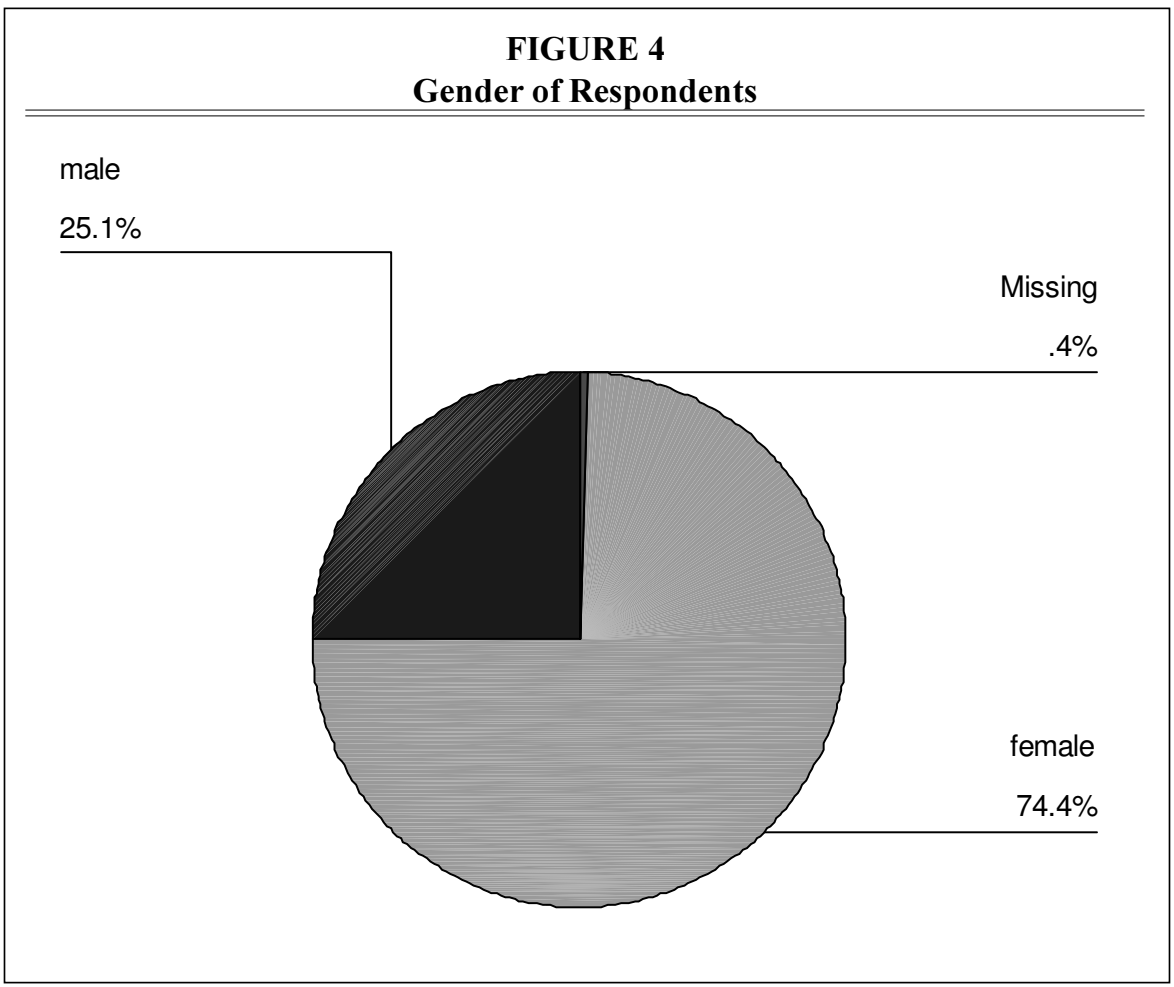

\section{FIGURE 5}

Awareness of Learning Style Theory

don't remember

$4.0 \%$

no

$13.7 \%$

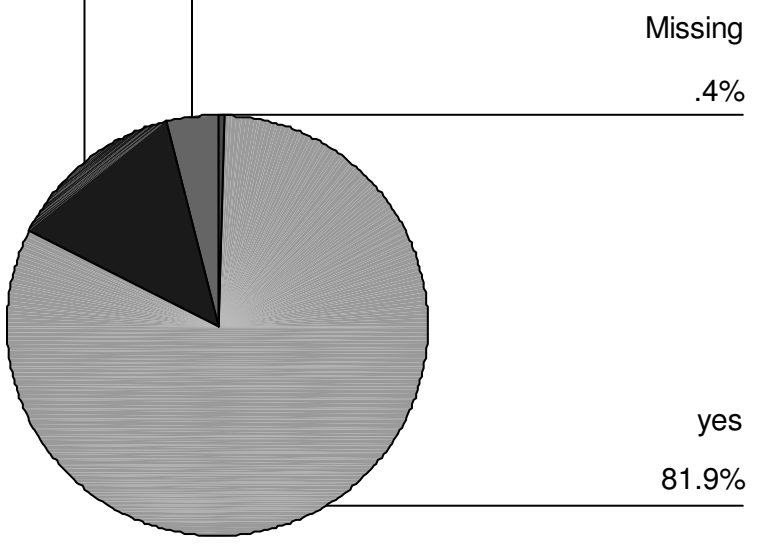




\begin{tabular}{|lccc|}
\hline \multicolumn{4}{c|}{ TABLE 4 } \\
Correlations with Awareness of Learning Style Theory \\
\hline \hline & $\begin{array}{c}\text { Spearman's } \\
\text { rho }\end{array}$ & $\begin{array}{c}\mathbf{N}=\text { number } \\
\text { of cases }\end{array}$ & $\begin{array}{c}\mathbf{p}=\text { significance } \\
\text { (one-tailed) }\end{array}$ \\
\hline $\begin{array}{l}\text { Number of hours spent on duties } \\
\text { related to instructing library users }\end{array}$ & .144 & & \\
Desire to learn more about instruction & & 895 & .000 \\
or education & .114 & 892 & .000 \\
Significant course work in education & .160 & 904 & .000 \\
K-12 teaching experience & .104 & 904 & .001 \\
Type of work organization & .135 & 903 & .000 \\
Gender & .094 & 900 & .002 \\
\hline
\end{tabular}

learning style theory. As might be expected, these correlations would seem to indicate that the more involved one has been with education as a professional, the more likely it is that one will have knowledge of learning style theory. Moreover, there was a slight, but significant, positive correlation between awareness of learning style theory and the desire to learn more about instruction or education. Females were slightly more likely to be aware of learning style theory than were males. Table 4 shows details on the calculated correlations.

\section{Validity of Learning Style Theory}

Most librarians who had heard of learning style theory felt that it was valid or very valid, with 70.8 percent of respondents falling into these two categories (figure 6). In addition, librarians with more course work in education and those with more interest in increasing their knowledge about instruction or education were slightly more likely to believe in the validity of learning style theory. Table 5 shows the calculated correlations.

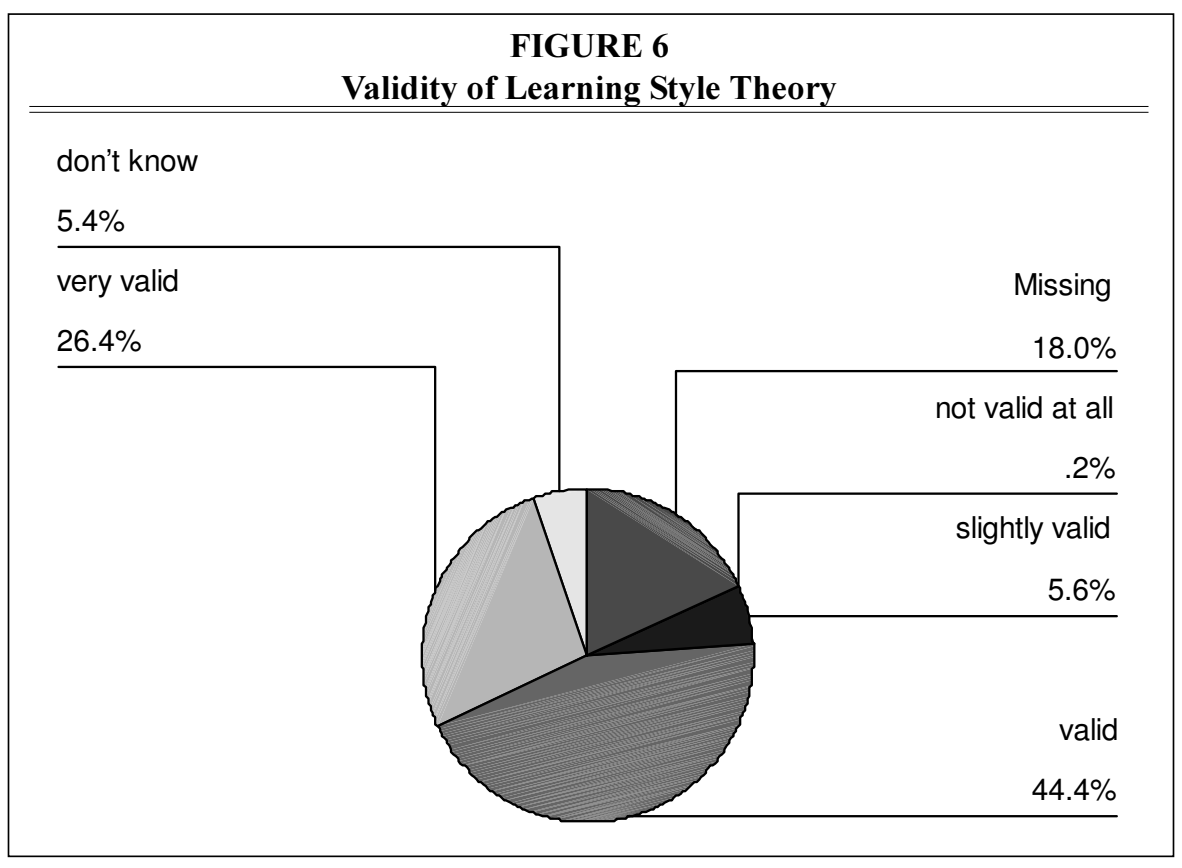




\begin{tabular}{|lccc|}
\hline \multicolumn{4}{|c|}{$\begin{array}{c}\text { TABLE 5 } \\
\text { Correlation with Ranking of Validity of Learning Style Theory }\end{array}$} \\
\hline \hline & $\begin{array}{c}\text { Spearman's } \\
\text { rho }\end{array}$ & $\begin{array}{c}\mathbf{N}=\text { number } \\
\text { of cases }\end{array}$ & $\begin{array}{c}\mathbf{p}=\text { significance } \\
\text { (one-tailed) }\end{array}$ \\
\hline $\begin{array}{l}\text { Interest in learning more about } \\
\text { instruction or education }\end{array}$ & .160 & 736 & .000 \\
Amount of course work in education & .092 & 393 & .034 \\
\hline
\end{tabular}

Most of the comments indicated that participants found learning style theory very valuable. One participant offered: "I believe that learning about learning styles was one of the single most helpful things I have encountered related to helping me in my own teaching. Specifically, I was made more aware of how different my own preferred learning style is from that of most of my students/patrons." Another participant wrote: "As both a librarian and teacher, I find learning style information invaluable in crafting instruction. Varied approaches, shifting from one exercise to another type involves and empowers students."

Some participants were very outspoken in their criticism, as shown by one response: "I am a doctoral student in organizational psychology and most of the learning styles stuff I've seen is absolutely worthless-about as valid as astrology! It terrifies me to see how blithely these tests are tossed around in educational settings." Particularly interesting were the comments of one respondent who wrote: "I am skeptical about the significance of learning styles. Certainly, something like learning styles exists, but I suspect for most library research topics, any good teaching style will be quite sufficient for communicating the subject matter."

It is certainly reasonable for a librarian to be skeptical about a theory somewhat peripheral to his or her own area of interest. However, it is interesting to note that some librarians feel that any teaching style will suffice to educate patrons about the library research process. Do some librarians feel that library research is an inferior subject, undeserving of the same level of thought or attention to instructional design as other academic subjects? Moreover, there may be a sense, at least among librarians working in institutions of higher education, that students at this stage of life ought to be able to adjust to the teaching style of the professor rather than the professor adjusting to the learning style of the student. These would make interesting topics for further study.

Perhaps the reason there are opponents of learning style theory among survey participants is because librarians have simply not delved deeply enough into the education literature to know whether the theories are valid. In addition, much of the literature of librarianship relating to learning style theory has been anecdotal, aimed at raising awareness and providing possible models. For the most part, library research into learning styles has not consisted of the kinds of rigorous sci-

\begin{tabular}{|lrc|}
\hline \multicolumn{3}{|c|}{ TABLE 6} \\
\multicolumn{1}{|c|}{ Tested for Learning Style (multiple response) } \\
\hline \hline Variable & Count & Percent of Cases \\
\hline Personality type & 682 & 87.1 \\
Preferred sensory modality & 171 & 21.8 \\
Preferred cognitive style & 127 & 16.2 \\
Environmental preferences & 26 & 3.3 \\
Don't remember & 71 & 9.1 \\
\hline Total responses & 1,077 & 137.5 \\
& & \\
125 missing cases; 783 valid cases & \\
\hline
\end{tabular}




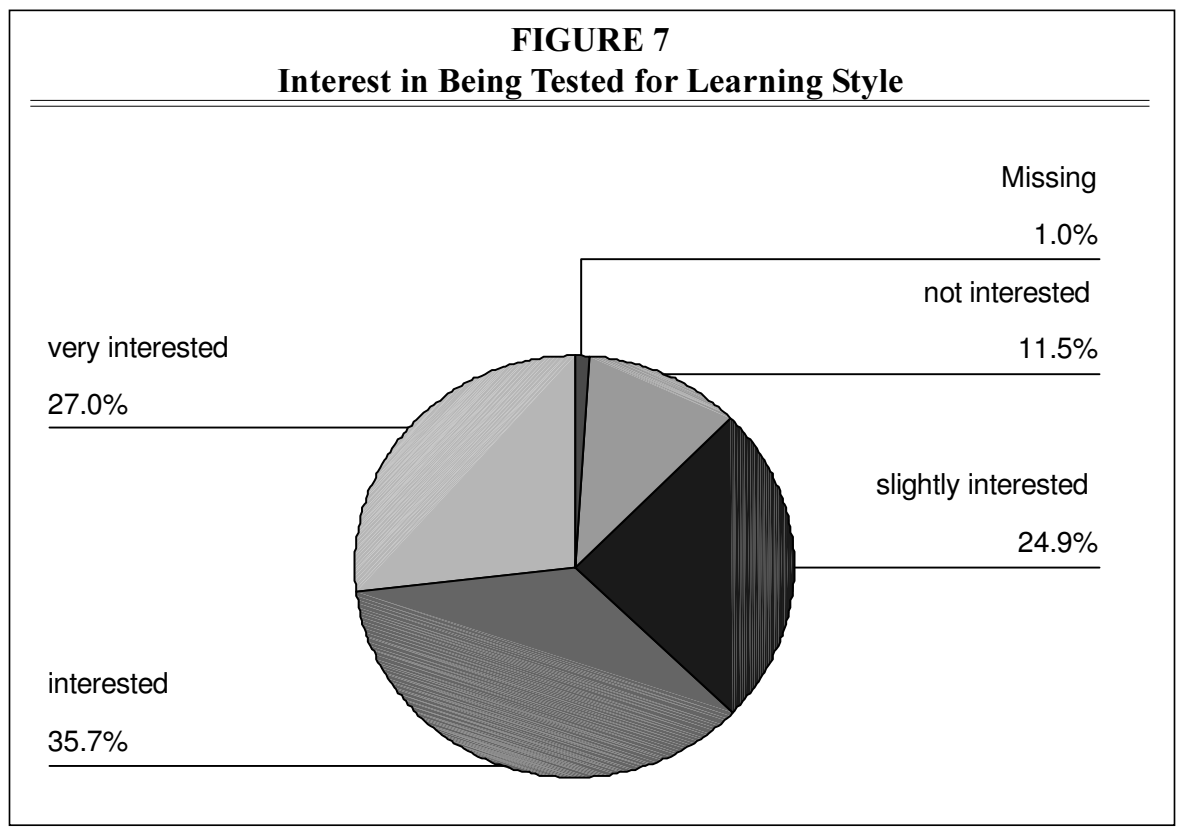

entific studies needed to test the validity of the theories as applied in the library setting. In the field of education itself, there is debate about the validity of various learning style constructs. Although many studies seem to prove the efficacy of customized learning style-sensitive instruction, other studies question these results.

\section{Learning Style Testing}

A majority of respondents $(87.1 \%)$ had been tested for personality type (Myers Briggs, etc.) (table 6). Fewer had been tested for their preferred sensory modality $(22.8 \%)$, cognitive type $(16.2 \%)$, or environmental preferences $(3.3 \%)$. One might speculate that the personality type testing was probably done as the result of the librarians' employment and not intended for any learning style applications. It may be that some do not remember testing performed early in their lives, with those results incorporated during the early years of their education. It also may be that many of these librarians had already completed their formal education before learning style theory began being broadly applied. As expressed by one participant, "My library school training was mostly before learning style became a significant issue, so I have had to pick up what I know primarily from conferences / workshops and reading." Forms of learning style testing are being incorporated into freshman orientation programs and

TABLE 7

\section{Correlation with Interest in Being Tested or Retested for Learning Style}

\begin{tabular}{lccc} 
Variable & $\begin{array}{c}\text { Spearman's } \\
\text { rho }\end{array}$ & $\begin{array}{c}\mathbf{N}=\text { number } \\
\text { of cases }\end{array}$ & $\begin{array}{c}\mathbf{p}=\text { significance } \\
\text { (one-tailed) }\end{array}$ \\
\hline $\begin{array}{l}\text { Desire to learn more about instruction } \\
\text { or education }\end{array}$ & .378 & 887 & .000 \\
Age & .142 & 877 & .000
\end{tabular}




\section{TABLE 7}

Where Librarians Learned about Learning Styles (multiple response)

\begin{tabular}{lcc}
\hline Variable & Count & $\begin{array}{c}\text { Percent } \\
\text { of Cases }\end{array}$ \\
\hline Professional reading & 506 & 68.5 \\
Conferences & 384 & 52.0 \\
On-the-job experience & 280 & 37.9 \\
Additional degree & 157 & 21.2 \\
Library school & 136 & 18.4 \\
Continuing education coursework & 110 & 14.9 \\
In-house training & 102 & 13.8 \\
Mentoring relationship & 40 & 5.4 \\
Don't remember & 40 & 5.4 \\
Distance learning & 34 & 4.6 \\
\hline Total responses & 1,789 & 242.1 \\
& & \\
169 missing cases; 739 valid cases & & \\
\hline
\end{tabular}

educations or perhaps because their awareness of their own learning styles might not be as high as more experienced participants. Table 7 shows the calculated correlations.

\section{Where Librarians Learn}

about Learning Style Theory Participants were most likely to be exposed to learning style theory in their daily work, while doing professional reading, or at conferences. A relatively small percentage $(18.4 \%)$ of participants indicated that they had learned about learning styles in library school. A complete breakintroduction to the university courses. ${ }^{17}$ Perhaps testing would be useful for new library school students as well.

A large percentage $(62.7 \%)$ of respondents indicated that they were interested or very interested in being tested or retested to determine their learning style (figure 7). This percentage is slightly less than one might expect, given the large number

\section{One of the biggest concerns ex- pressed by participants was that it is difficult or impossible to address different learning styles in the typical one-shot instruction session.}

of librarians who feel that learning styles are valid. This may be because many librarians do not plan on returning to a formal learning environment or because they have enough of an understanding of their own learning styles through their own past experience and past testing. Individuals who feel a strong desire to learn more about instruction or education also are slightly more likely to have a stronger interest in being tested or retested for learning style. Younger participants were slightly more likely to indicate an interest in being tested as well, perhaps because of a greater likelihood of furthering their down of responses is shown in table 8 . Although this does not speak well for the penetration of this theory into library school curricula, it does reinforce the ability of librarians to share knowledge through the professional literature and conferences.

It is not surprising that library school ranks fifth on the list. Diana Shonrock and Craig Mulder noted that, historically, a relatively small percentage of library schools have offered course work in bibliographic instruction. ${ }^{18}$ Ronald R. Powell also found that a surprisingly small percentage of librarians indicated that library school was where they acquired their bibliographic instruction knowledge. ${ }^{19}$

\section{Desire to Learn More about Education and Instruction}

Nearly 84 percent of respondents indicated that they were interested or very interested in learning more about instruction or education. Given the increasing focus on information literacy and patron education, this is undoubtedly a positive thing. Some librarians reported on their efforts to educate their colleagues about learning style theory. According to one respondent, 


\begin{tabular}{|lcc|}
\hline \multicolumn{3}{|c|}{$\begin{array}{c}\text { TABLE 8 } \\
\text { Classroom Teaching Methods Used } \\
\text { (multiple response) }\end{array}$} \\
\hline Variable & Count & $\begin{array}{r}\text { Percent } \\
\text { of Cases }\end{array}$ \\
\hline Online demonstrations & & 84.5 \\
Online demos with simultaneous student & 755 & \\
$\quad$ experimentation & 456 & 51.0 \\
Humor or stories & 444 & 49.7 \\
Web-based instruction & 435 & 48.7 \\
Assignments & 425 & 47.5 \\
Individual exercises & 407 & 45.5 \\
Class discussions & 401 & 44.9 \\
Contextual learning & 381 & 42.6 \\
Collaborative/cooperative learning & 378 & 42.3 \\
Copies of lecture notes/slides provided & 340 & 38.0 \\
Graphic organizers & 231 & 25.8 \\
Computer-assisted instruction & 138 & 15.4 \\
Flexible classroom design & 132 & 14.8 \\
Student-controlled learning & 123 & 13.8 \\
Distance learning & 94 & 10.5 \\
I do not participate in classroom-based & & \\
instruction & 93 & 10.4 \\
Audiotaped or videotaped instruction & 54 & 6.0 \\
\hline Total responses & 5,287 & 591.4 \\
& & \\
14 missing cases; 894 valid cases & & \\
\hline
\end{tabular}

audio- or videotaped instruction. Though these were among the least popular techniques, they each garnered a respectable number of users. Table 9 represents a complete breakdown of respondents' instructional methods.

The variety of teaching methods was somewhat surprising considering the degree of negativity expressed in survey comments toward applying learning style theory in libraries. One of the biggest concerns expressed by participants was that it is difficult or impossible to address different learning styles in the typical one-shot instruction session. "I would love to do more with learning styles, but a fifty

For many years I was like a "broken record" reminding colleagues of difficult learning styles, especially regarding online, CD-ROM, and Web databases. One group of people felt that handouts on a particular database should take care of most questions. Experience showed that not all library users could learn from a written explanation-some needed oral explanations, some a combo, some needed hands-on with coaching from a library staff member, etc. One size does not fit all users.

\section{Teaching Methods Used}

Librarians reported using a variety of teaching methods in the classroom. The categories with the most adherents, as one might expect, were lectures and online demonstrations. Some of the least frequently used techniques were flexible classroom design, distance learning, and

minute BI session doesn't leave much time for anything," wrote one participant. Gwendolyn Mettetal, Cheryl Jordan, and Sheryll Harper reported the same sort of time concerns expressed by schoolteachers and suggested that one way to gradually incorporate multiple intelligence accommodations into the curriculum is to incorporate into any given unit at least one activity geared toward each learning style. ${ }^{20}$

Some librarians expressed doubts about the validity of some instructional methods. As one respondent noted, "An unfortunate trend in recent education seems to be the 'team' approach to assignments. Individual achievement is no longer considered the ideal, apparently. Many students at the reference desk complain that their grade is going to be lowered because one or more members of their 'assignment team' is slacking or 
coasting, content to settle for a lower grade based on other students' efforts."

Other librarians were enthusiastic about embracing learning styles in the classroom: "I love teaching! Providing library instruction enables me to combine teaching and reference librarianship. In all my classes, I try 'to tell' a little, 'to show' a lot, and to allow sufficient time in each section of instruction for 'handson' experience." Another respondent wrote: "My current approach to teaching different learning styles is to create as many active learning opportunities as possible to give students a way to show me that they are learning what I think I'm teaching." A third respondent addressed the time concern by saying, "It is absolutely essential to incorporate learning opportunities that address differing learning styles into library instruction. It is time for all teaching, but more so for our profession, for we often don't get multiple opportunities with a class or group of learners."

\section{Conclusion}

Learning style and education in general are areas of ongoing interest for librarians. This would seem a logical outgrowth of several trends, including the advent of the information age, the adoption of information literacy standards, and the need for constant training and retraining in so many fields, including librarianship.

Some have argued, as Herbert S. White did in his 1991 opinion piece, that bibliographic instruction knowledge is best acquired on the job. ${ }^{21}$ However, a great deal has changed in the ten years since White's article appeared. Librarians in schools and higher education continue to focus on patron education and have become more rigorous in their approaches to implementing information literacy standards in their curricula. Public, technical services, and special librarians-who have traditionally been somewhat less concerned with education and instruction-have recently been focusing more on these areas. Regardless of institution type or position, librarians are bringing their patrons, themselves, and their staffs up to speed on new technologies, especially in the areas of technology literacy and the Internet.

The information world in which librarians operate is increasingly a dynamic, changing environment, necessitating constant attention to education and reeducation. It could be argued that education is no longer the sole purview of bibliographic instruction librarians; professionals in all areas of librarianship need a better understanding of education and instruction in order to prosper in their careers. As a result, library schools need to bolster their efforts to ensure that students recognize the importance of teaching to librarians, regardless of whether they plan to embark on a library instruction career. Among the many respondents who expressed this sentiment was one who wrote: "I wish library schools had taught this when I was working on my MLS."

\section{Suggestions for Future Research}

Required course work in education and instruction seems to be indicated for all students who intend to become librarians, but what can be done for the librarians who are already in the trenches? It would seem that increasing the attention in the professional literature to this area would be indicated. Two areas of research particularly stand out as needing further attention. First, librarians need to put aside their concerns about time limitations and develop and share more models of learning style-sensitive instruction as applied in both the one-shot and the extended contact settings. This will not be easy because it will require an outlay of time and intellectual resources at a time when many librarians already feel stretched to the breaking point. Perhaps many more of these models already exist but have yet to be published. After these models have been developed, they need to be tested in a rigorous, scientific manner so that librarians can know what works and what does not. 


\section{Notes}

1. Thomas C. DeBello, "Comparison of Eleven Major Learning Styles Models: Variables, Appropriate Populations, Validity of Instrumentation and the Research Behind Them," Journal of Reading, Writing, and Learning Disabilities International 6 (July-Sept. 1990): 203-22.

2. Rita Stafford Dunn and Kenneth J. Dunn, Teaching Students through Their Individual Learning Styles (Reston, Va.: Reston Publishing, 1978).

3. Howard Gardner, Intelligence Reframed: Multiple Intelligences for the $21^{\text {st }}$ Century (New York: Basic Books, 1999).

4. John Naim Harb, et al., Teaching through the Cycle: Application of Learning Style Theory to Engineering Education at Brigham Young University (Provo, Utah: Bringham Young Univ. Pr., 1995).

5. Daniel D. Barron, "Doing It with Style or Different Strokes for Different Folks: Learning Styles for School Library Media Specialists," School Library Media Activities Monthly 14 (Oct. 1997): $48-50$.

6. Sonia Bodi, "Teaching Effectiveness and Bibliographic Instruction: The Relevance of Learning Styles," College E Research Libraries 54 (Mar. 1990): 113-19; — , "Learning Style Theory and Bibliographic Instruction: The Quest for Effective Bibliographic Instruction," in Academic Libraries: Achieving Excellence in Higher Education. Proceedings of the Sixth National Conference of the Association of College and Research Libraries, Salt Lake City, Utah, April 12-14, 1992 (Chicago: ACRL, 1992).

7. Elizabeth J. McNeer, "Learning Theories and Library Instruction," Journal of Academic Librarianship 117 (Nov. 1991): 294-97.

8. Eileen E. Allen, "Active Learning and Teaching: Improving Postsecondary Library Instruction," Reference Librarian 52 (1995): 89-113.

9. Dorothy N. Bowen, "Learning Style-based Bibliographic Instruction," International Library Review 20 (July 1988): 405-13.

10. Sally G. Wayman, "The International Student in the Academic Library," Journal of Academic Librarianship 9 (Jan. 1984): 336-41.

11. Rita Dunn, "Learning Styles of the Multiculturally Diverse," Emergency Librarian 20 (Mar./ Apr. 1993): 24-32; - Mark Beasley, and Karen Buchanan, "What Do You Believe about How Culturally Diverse Students Learn?" Emergency Librarian 22 (Sept./Oct. 1994): 8-14.

12. Keith Gresham, "Experiential Learning Theory, Library Instruction, and the Electronic Classroom," Colorado Libraries 25 (spring 1999): 28-31.

13. Terri Holtze, "Applying Learning Style Theory to Web Page Design," Internet Reference Services Quarterly 5 (2000): 71-80.

14. Randall Hensley, "Learning Style Theory and Learning Transfer Principles During Reference Interview Instruction," Library Trends 39 (winter 1991): 203-9.

15. Marie Carbo, "Reading Styles Times Twenty," Educational Leadership 54 (Mar. 1997): 38-42.

16. Jin M. Choi, "Learning Styles of Academic Librarians," College $\mathcal{E}$ Research Libraries 50 (Nov. 1989): 691-99.

17. Betsy O. Barefoot and Paul P. Fidler, 1994 National Survey of Freshman Seminar Programs: Continuing Innovations in the Collegiate Curriculum (Columbia, S.C.: National Resource Center for the Freshman Year Experience \& Students in Transition, University of South Carolina, 1996).

18. Diana Shonrock, and Craig Mulder, "Instruction Librarians: Acquiring the Proficiencies Critical to Their Work," College \& Research Libraries 54 (Mar. 1993): 137-49.

19. Ronald R. Powell, "Sources of Professional Knowledge for Academic Librarians," College $\mathcal{E}$ Research Libraries 49 (July 1988): 332-40.

20. Gwendolyn Mettetal, Cheryl Jordan, and Sheryll Harper, "Attitudes toward a Multiple Intelligences Curriculum," Journal of Educational Research 91 (Nov./Dec. 1997): 115-19.

21. Herbert S. White, "Bibliographic Instruction and the Library School Curriculum," Journal of Education for Library and Information Science 32 (fall/winter 1991): 194-202. 